(C) 2012

Диченко О. Ю., старший викладач

Полтавська державна аграрна академія

\title{
МІЖСИСТЕМНИЙ МЕТОД ПРОГНОЗУВАННЯ МАСОВОГО РОЗМНОЖЕННЯ ОСНОВНИХ ШКІДНИКІВ БУРЯКІВ ЦУКРОВИХ
}

\section{Рецензент - кандидат сільськогосподарських наук М. А. Піщаленко}

\begin{abstract}
Наведено історичні відомості про масові розмноження основних шкідників иукрових буряків у Лівобережному Лісостепу України (назва видів, роки масових розмножень у просторі й часі). На основі міжсистемного методу прогнозування розроблені алгоритми масового розмноження основних шкідників иукрових буряків, а саме: совки озимої, метелика лучного, совки капустяної, совки-гамма і довгоносика звичайного, а також прогноз початку наступних спалахів їхньої чисельності на період до 2018 року.
\end{abstract}

Ключові слова: прогнозування, масові розмноження, міжсистемний метод, икідники, буряки чукрові, алгоритми, чисельність, синхронність, сонячна активність.

Постановка проблеми. Спалах чисельності i міграції шкідливих комах, у тому числі й шкідників буряків цукрових, відомі 3 давніх давен, але й досі прогнозування динаміки їх популяцій у майбутньому розроблене недостатньо.

Тому виникає потреба у розробленні алгоритму масового розмноження совки озимої, метелика лучного, совки капустяної, совки-гамма і довгоносика звичайного.

Аналіз основних досліджень і публікацій, у яких започатковано розв'язання проблеми. Перша спроба теоретичного обгрунтування вказаної проблеми належить відомому українському екологу С. П. Іванову (1936 р.), але тільки у 1975 році ця проблема знову набула неабиякої гостроти, особливо після глобального спалаху масового розмноження метелика лучного на величезній території (від Прибалтики до Далекого Сходу, а також у країнах Західної Європи й навіть у Китаї).

Нині для прогнозування масових розмножень шкідливих комах застосовують переважно якісний метод (Білецький, Туренко, 2002), або так званий міжсистемний метод. Інформаційним забезпеченням цього методу $є$ історичні хроніки масових розмножень комах у буд-якому регіоні. Як відомо, історичні хроніки уже містять у собі інформацію про інтегральний вплив у минулому на кінцеву динаміку популяцій комах практично всіх середовищних чинників (космічних, геофізичних, тропічних та ін.). А комахи, як одна iз стародавніх груп тварин (3'явилися на землі понад 300 млн років тому), мають генетичну «пам'ять» минулого й, відповідно, передають інформацію від покоління до покоління, від популяції до популяції за допомогою генетичного коду згідно з еволюційною тріадою: спадковість, мінливість, природний добір, насамперед, у період масових розмножень, що відбуваються в часі циклічно, тобто через рівні проміжки часу. До того ж повторюваність масових розмножень комах у часі ще містить ознаки минулого, але вже на новій основі. Доведено, що при цьому змінюється генетична й екологічна структури (організація) популяцій, а тому всі без винятку екологічні прогнози мають імовірнісний характер (Бальшаков, 1983).

Мета досліджень та методика їхнього проведення. Метою роботи було узагальнення і доповнення історичних відомостей про масові розмноження комах-шкідників буряків цукрових. Враховуючи активність і пріоритетність прогнозування масових розмножень основних шкідників буряків цукрових у Лівобережному Лісостепу України, нами узагальнені й значно доповнені регіональні дані про масові розмноження совки озимої, метелика лучного, капустяної совки, совки-гама і бурякового звичайного довгоносика. На основі міжсистемного методу прогнозування розроблено прогноз масового розмноження названих вище шкідників.

Результати досліджень. Хроніка масових розмножень основних икідників буряків цукрових у Лівобережному Лісостепу Украӥни (назва видів, роки масових розмножень у просторі $\check{u}$ yaci)

Совка озима - Scotia segetum Schiff. Масові розмноження цього шкідника в Лісостепу України спостерігалися в 1813-1819, 1823-1825, 1836-1842, 1846-1852, 1855-1856, 1861-1868, 1871-1880, 1882-1888, 1892-1896, 1899-1900, 1907-1909, 1915-1919, 1923-1925, 1934-1941, 1946-1950, 1956-1957, 1964-1968, 1971-1978, 
1982-1985, 1995-2003, 2007-2009 роках.

Синхронність масових розмножень совки озимої: 1813-1819 pp. Прибалтика, СанктПетербурзька губернія, Україна; 1823-1825 південь Франції, Росія, Україна; 1836-1842 - Західна і Східна Європа, Росія, Україна; 1846-1852 - Росія (18 губерній), Україна; 1855-1856 - Росія, Україна; 1861-1868 - Росія, Україна; 18711872 - Акмолінська, Снісейська, Омська, Псковська, Новгородська, С.-Петербурзька, Кокчетавська губернії, Україна; 1880-1881 - Росія, Україна; 1892-1896 - Німеччина, Росія, Україна; 1899-1900 - Росія, Україна; 1907-1909 - Росія, Угорщина, Україна, Чехословаччина, Фінляндія, Югославія; 1915-1919 - Англія, Африка, Угорщина, Болгарія, Німеччина, Росія, Сгипет, Україна, Чехословаччина; 1923-1925 - Австрія, Америка, Бразилія, Данія, Закавказзя, Іспанія, Італія, Корея, Марокко, Росія, Україна, Чехословаччина, Японія; 1936-1941 - Казахстан, Киргизія, Росія, Україна; 1946-1950 - Угорщина, Казахстан, Киргизія, Росія, Сербія, Румунія, Україна, Чехословаччина, Югославія; 1955-1956 - Угорщина, Болгарія, Росія, Сербія, Чехія, Хорватія; 1971-1975 - Німеччина, Росія, Україна; 19821987 - Німеччина, Польща, Росія, Україна; 1995-2003 - Росія, Греція, Словакія, Україна.

Метелик лучний - Margaritia sticticalis $L$. Перше масове розмноження цього шкідника в Україні було в 1686 р. (Літопись Самовидця, 1878), друге - 1769 р. за період (1854-2000 рр.) в Україні було 14 масових розмножень метелика лучного: 1854-1857, 1864-1869, 1873-1880, 1892-1893, 1900-1903, 1910-1916, 1919-1922, 1925-1932, 1935-1937, 1947-1950, 1956-1957, 1972-1978, 1986-1988, 200-2002 pp. сторічні цикли: 1873-1972 рр.; 1900-2000 роки.

Синхронність масових розмножень метелика лучного: 1901 - Болгарія, Угорщина, Росія, Україна; 1909-1910 - Північна Америка, Росія, Україна; 1914-1915 - Болгарія, Угорщина, Румунія, Україна, Югославія; 1921-1922 - Болгарія, Угорщина, Росія, Україна, Чехословаччина; 1929-1930 - Болгарія, Угорщина, Німеччина, Польща, Північна Маньчжурія, Росія, Україна, Югославія; 1935 - Росія, Румунія, Україна; 1975 - Болгарія, Німеччина, Польща, Росія, Північний Казахстан, Україна, Чехословаччина, Югославія; 1984-1989 - Калмикія, Східний Сибір, Далекий Схід; 1986-1988 - Росія, Україна, Китай; 20002002 - Росія, Україна.

Совка капустяна - Mamestra brassicae $L$. В Україні спалахи масового розмноження совки капустяної були в наступні роки: $1871,1878-$ 1879, 1896, 1904-1905, 1908-1909, 1912-1914, 1922-1923, 1927-1928, 1932-1933, 1937-1938, 1956-1957, 1964-1965, 1969-1970, 1973-1975, 1985-1986, 1990-1991, 1997-1998, 2000-2002.

Синхронно масові розмноження совки капустяної відбувалися: 1871 р. - Білорусь, Україна; 1878-1879 - Білорусь, Україна; 1964-1965 Угорщина, Росія, Сербія, Україна; 1969-1970 Угорщина, Сербія, Україна; 1985-1986 - Сербія, Україна.

Совка-гамма - Autographa gamma L. Масові розмноження цього шкідника зареєстровані в наступні роки: 1826-1829, 1833, 1839-1840, 1854, 1855-1861, 1864-1865, 1870-1871, 18781879, 1888-1889, 1899-1900, 1910, 1912-1913, 1922, 1928-1930, 1946, 1953, 1962-1963, 1988, 1995-1996.

Синхронні масові розмноження: 1826-1829Нідерланди, Східна Пруссія, Росія, Україна; 1833 - Росія, Україна; 1839 - Росія, Україна; 1854 - Росія, Україна; 1860 - Росія, Україна; 1871 - Австрія, Росія, Україна; 1878-1879 - Росія, Україна; 1899-1900 - Англія, Росія, Україна; 1912-1913 - Росія, Україна; 1922 - Росія, Україна; 1928-1930 - Німеччина, Данія, Польща, Україна, Чехословаччина; 1946 - Німеччина, Данія, Росія, Південна Швеція, Південна Фінляндія; 1953-1954 - Росія, Україна; 1962-1963 Угорщина, Україна. Сторічні цикли масового розмноження цього шкідника: 1864-1963; 1888 1988 роки.

Довгоносик буряковий звичайний - Bothynoderes punctiventris Germ.

Масові розмноження цього шкідника мали місце в 1851-1855, 1868-1869, 1875-1877, 18801886, 1892-1893, 1896-1897, 1904-1906, 19091911, 1920-1922, 1928-1930, 1932-1940, 19471949, 1952-1957, 1963-1964, 1973-1976, 19861988, 2000-2002 роках. Із сімнадцяти спалахів чисельності 15 (або 88 \%) починалися точно в роки посух. Одночасно масові розмноження мали місце в 1905p. - Угорщина, Україна; 19221923 - Болгарія, Україна; 1937-1938 - Угорщина, Україна; 1947-1948 - Німеччина, Україна; 1962-1964 pр. - Болгарія, Україна, Югославія.

У 1985 р. Є. М. Білецьким для прогнозування масових розмножень шкідливих комах були вперше використані роки різких змін сонячної активності (CA), або так звані сонячні репери (Белецкий, 1985). Відомі вони нині з 1700 по 2010 pp. і використовуються для порівняльного аналізу сонячно-земних зв'язків. 
СІЛЬСЬКЕ ГОСПОДАРСТВО. РОСЛИННИЦТВО

1. Масові розмноження основних икідників буряків цукрових у Лівобережному Лісостепу Украӥни і різкі зміни сонячної активності (СА)

\begin{tabular}{|c|c|c|}
\hline \multirow{2}{*}{ Назва шкідника } & \multicolumn{2}{|c|}{ Початок наступних масових розмножень, \% } \\
\cline { 2 - 3 } & у роки різких змін СА & в інші роки \\
\hline Совка озима & 95,2 & 4,8 \\
\hline Метелик лучний & 92,8 & 7,2 \\
\hline Совка капустяна & 77,8 & 22,2 \\
\hline Совка-гамма & 79,0 & 21,0 \\
\hline Довгоносик буряковий звичайний & 77,8 & 22,8 \\
\hline
\end{tabular}

Роки різких змін сонячної активності: 1705 , $1706,1708,1711,1712,1716,1718,1719,1723$, $1727,1729,1732,1733,1734,1736,1738,1741$, $1744,1745,1748,1749,1750,1751,1754,1755$, $1757,1761,1762,1765,1766,1769,1771,1772$, $1773,1774,1775,1777,1778,1780,1782,1784$, $1786,1788,1790,1793,1795,1798,1799 ; 1801$, $1805,1807,1810,1813,1815,1816,1818,1821$, $1823,1826,1829,1831,1833,1836,1837,1838$, $1841, \quad 1843,1845, \quad 1847, \quad 1848,1849, \quad 1850$, $1854,1855,1856,1859,1860,1861,1862,1865$, 1867, (1868), 1870, 1871, 1872, 1873, 1874, 1875, $1877,1878,1880,1882,1883,1884,1885,1886$, 1887, 1890, 1892, 1893, 1894, 1896, 1899; 1900, 1901, 1903, 1905, 1906, 1907, 1908, 1910, 1911, 1912, 1913, 1915, 1917, 1918, 1920, 1922, 1923, 1924, 1925, 1928,1929, 1932, 1933, 1934, 1935, 1936, 1937, 1939, 1940, (1942), 1943, 1943, 1944, 1946, 1947, 1948, 1950, 1952, 1953, 1954, 1956, 1961, 1963, 1964, 1966, 1967, 1968, 1969, 1971, (1972), 1973, 1975, 1977, 1978, 1979, 1981, 1982, 1983, 1984, 1986, 1987, 1988, 1989, 1990, 1991, 1993, 1994, 1995, 1996, 1998, 1999, 2000, 2003, 2006, 2007, 2009, 2010. У дужках наведені роки сонячних реперів, коли різкі зміни сонячної активності мали місце в середині року (з січня по грудень включно).

Із метою обгрунтування можливості прогнозування масового розмноження основних шкідників у Лівобережному Лісостепу України, ми виконали порівняльний аналіз спалахів їхньої чисельності у зв'язку з різкими змінами сонячної активності (табл. 1).

Із даної таблиці бачимо, що переважна більшість $(77,8-95,2 \%)$ масових розмножень основних шкідників буряків цукрових у регіоні відбувалися в роки різких змін сонячної активності, або в так звані роки сонячних реперів. Це дає підстави щодо застосування міжсистемного методу прогнозування їх масових розмножень. Сутність названого методу полягає в тому, що за поведінкою однієї системи - різких змін сонячної активності - прогнозується наступна - масове розмноження конкретного шкідника. При цьому перша система виступає в якості прогнозуючої, друга - прогнозованої. Перевага методу полягає в тому, що навіть за обмежених знань конкретних механізмів динаміки чисельності він дає змогу прогнозувати початок чергового масового розмноження того чи іншого шкідника в будь-якому регіоні. Іншими словами, він відповідає на одне з актуальних питань: де і коли слід очікувати початку наступного масового розмноження?

Інформаційним забезпеченням міжсистемного методу прогнозування $\epsilon$ історико-статистичні матеріали (хроніка) про масові розмноження шкідливих комах.

На основі міжсистемного методу нами розроблені алгоритми прогнозування масового розмноження совки озимої, капустяної, совкигамма, метелика лучного і довгоносика бурякового звичайного для названого регіону.

Алгоритм прогнозування масового розмноження совки озимої у Лівобережному Лісостепу України

За період 1813-2007 pp. у названому регіоні було зареєстроване 21-е масове розмноження совки озимої: 1813-1819, 1823-1825, 1836-1842, 1846-1852, 1855-1856, 1861-1868, 1871-1880, 1882-1888, 1892-1896, 1899-1900, 1907-1909, 1915-1919, 1923-1925, 1934-1941, 1946-1950, 1956-1957, 1964-1968, 1971-1978, 1982-1985, 1995-2003, 2007-2009 рр. Середній період між черговими масовими розмноженнями -9 років. Із 21-го масового розмноження совки озимої 20 $(95,2 \%)$ точно співпали з роками різких змін сонячної активності й одне $(4,8 \%)$ було через рік після сонячного репера. Розподіл масових розмножень цього шкідника в межах сонячних циклів було наступним:

\begin{tabular}{|c|c|c|c|}
\hline Роки від сонячних реперів & -1 & 0 & +1 \\
\hline Частота масових розмножень & 0 & 20 & 1 \\
\hline Ймовірність їхнього початку, \% & 0,0 & 95,2 & 4,8 \\
\hline
\end{tabular}

Примітка: 0 - роки сонячних реперів; -1 - за один рік до реперу; +1 - через один рік після реперу. 
Із розподілу масових розмножень виходить, що 395 \%-ю вірогідністю можна прогнозувати початок чергового масового розмноження совки озимої точно в епоху сонячних реперів, тобто в роки різких змін сонячної активності зі $100 \%-$ у рік сонячних реперів і через рік після них. Останнє масове розмноження цього шкідника було в 19952003 роках. Із максимумом у 1998 р., до року максимуму (1998) додаємо 9 років (середній період) i маємо, що початок наступного розмноження цього шкідника слід було очікувати в 2007-2008 рр. (прогноз справдився). Максимум останнього масового розмноження в Лівобережному Лісостепу України був у 2007 р., до нього додаємо середній період між спалахами чисельності 9 років і маємо: початок наступного масового розмноження совки озимої у регіоні слід очікувати в 2016 році.

Алгоритм прогнозу масового розмноження метелика лучного в Лівобережному Лісостепу України

За останні 147 років у Лівобережному Лісостепу України відбулося 14 масових розмножень метелика лучного в наступні роки: 1854-1857, 1865-1869, 1873-1880, 1892-1893, 1910-1916, 1919-1922, 1925-1932, 1935-1937, 1947-1950, 1956-1957, 1972-1978, 1986-1988, 2000-2002. Середня повторюваність між початком чергових спалахів чисельності $\approx 10$ років. За цей період із 14 спалахів масового розмноження 13, або $92,8 \%$, точно збігалися 3 роками сонячних реперів і лише одне масове розмноження (в 19191922 рр.) відбулося через один рік після реперу. Розподіл масових розмножень метелика лучного в межах сонячних циклів був наступним:

\begin{tabular}{|c|c|c|c|}
\hline Роки від сонячних реперів & -1 & 0 & +1 \\
\hline Частота масових розмножень & 0 & 13 & 1 \\
\hline Ймовірність їхнього початку, \% & 0,0 & 92,8 & 7,2 \\
\hline
\end{tabular}

Примітка: 0 - роки сонячних реперів; -1 - за один рік до реперу; +1 - через один рік після реперу.

Із розподілу масових розмножень метелика лучного випливає: 3 імовірністю до 33 \% можна прогнозувати початок наступного масового розмноження його в регіоні точно в роки сонячних реперів і зі $100 \%-$ у рік сонячних реперів і через один рік після них. Відомо, що останнє масове розмноження метелика лучного в названому регіоні і на півдні України відбулося в 20002002 pр. із максимумом у 2001 р., до нього додаємо, відповідно, 10 років (середній період між спалахами) і виходить - початок наступного слід очікувати в 2011 році (Білецький, 2004). Даний прогноз виправдався: дійсно, в лісостеповій i степовій зонах України, крім АРК, почалося чер- гове масове розмноження метелика лучного. За даними Є. М. Білецького, максимум спалаху чисельності метелика 3 імовірністю $93 \%$ слід очікувати в 2012 році. До 2012 р. додаємо, відповідно, 10 років (середній період) і прогнозуємо початок чергового масового розмноження цього шкідника в лісостеповій зоні України у 2022 році (із ймовірністю $93 \%$ ).

Алгоритм прогнозу масового розмноження совки капустяної у Лівобережному Лісостепу Украӥни

За період із 1871 по 2000 рр. у регіоні відбулося 18 масових розмножень совки капустяної: 1871, 1878-1879, 1896, 1904-1905, 1908-1909, 1912-1914, 1922-1923, 1927-1928, 1932-1933, 1937-1938, 1956-1957, 1964-1965, 1969-1970, 1973-1975, 1985-1986, 1990-1991, 1997-1998, 2000-2002 роках. Середній період між черговим масовим розмноженням - 7 років. У межах сонячних циклів розподіл масових розмножень совки капустяної у Лівобережному Лісостепу України був наступним:

\begin{tabular}{|c|c|c|c|}
\hline Роки від сонячних реперів & -1 & 0 & +1 \\
\hline Частота масових розмножень & 1 & 14 & 3 \\
\hline Ймовірність їхнього початку, \% & 5,5 & 77,8 & 16,7 \\
\hline
\end{tabular}

Примітка: 0 - роки сонячних реперів; -1 - за один рік до реперу; +1 - через один рік після реперу.

Із розподілу масових розмножень совки капустяної виходить, що 3 ймовірністю понад 77 \% можна прогнозувати початок наступного масового іiі розмноження точно в роки сонячних реперів 94,5 \%-ю - у рік реперів і через один рік опісля. Останнє масове розмноження совки капустяної було в лісостеповій зоні України в 2000-2002 pр., 3 максимумом у 2001 році. До року максимуму додаємо 7 років і виходить, що наступне було в 2008 році (даний прогноз справдився), а потім до 2008 року додаємо 7 років і маємо, що наступне масове розмноження цього шкідника слід очікувати в 2015 році.

Алгоритм прогнозу масового розмноження совки-гамма в Лівобережному Лісостепу України

За останні 170 років (1826-1995) у Лісостеповій Україні було 19 масових розмножень совкигамма, зокрема в 1826-1829, 1833, 1839-1840, 1854, 1859-1861, 1870-1871, 1878-1879, 18881889, 1899-1900, 1910, 1912-1913, 1922, 19281930, 1946, 1953, 1962-1963, 1988, 1995-1996 роках.

Середній період між черговими масовими розмноженнями - 9 років. У межах сонячних циклів розподіл масових розмножень совкигамма був наступним: 


\begin{tabular}{|c|c|c|c|}
\hline \hline Роки від сонячних реперів & -1 & 0 & +1 \\
\hline Частота масових розмножень & 1 & 15 & 3 \\
\hline Ймовірність їхнього початку, \% & 5,2 & 79,0 & 15,8 \\
\hline
\end{tabular}

Примітка: 0 - роки сонячних реперів; -1 - за один рік до реперу; +1 - через один рік після реперу.

Із наведеного розділу масових розмножень виходить, що з ймовірністю 79 \% можна прогнозувати початок наступного точно в роки сонячних реперів і через плюс один рік з імовірністю (79 \% + 15,8 \%), тобто більше ніж $94 \%$ у рік реперів і через один рік опісля. Відомо, що останне масове розмноження совки-гамма в регіоні відбулося в 1995-1996 pp. із максимумом чисельності в 1995 році; до нього додаємо, відповідно, 9 років і виходить, що наступне повинно було бути в 2004 році (цей прогноз справдився). Далі до 2004 р. додаємо 9 років і прогнозуємо початок наступного (у 2013 році). Слід зауважити, що 100 років тому, а саме у 1912-1913 рр., у названому регіоні також відбувалося масове розмноження цього шкідника.

Алгоритм прогнозу масового розмноження бурякового звичайного довгоносика в Лівобережному Лісостепу Украӥни

За останні 158 років (1851-2009) відбулося 18 спалахів масового розмноження цього шкідника, а саме: в $1851-1855,1868-1869,1875-$ 1877, 1880-1886, 1896-1897, 1904-1906, 19091911, 1920-1922, 1928-1930, 1932-1940, 19471949, 1952-1957, 1963-1964, 1973-1976, 19861988, 2000-2002, 2009-2011 роках. Середній пе- ріод між черговими спалахами масових розмножень - 9 років. Розподіл масових розмножень довгоносика звичайного бурякового в межах сонячних циклів був наступним:

\begin{tabular}{|c|c|c|c|}
\hline Роки від сонячних реперів & -1 & 0 & +1 \\
\hline Частота масових розмножень & 0 & 14 & 4 \\
\hline Ймовірність їхнього початку, \% & 0,0 & 77,8 & 22,2 \\
\hline
\end{tabular}

Примітка: 0 - роки сонячних реперів; $-1-$ - ад один рік до реперу; +1 - через один рік після реперу.

Із даного розподілу видно, що з імовірністю 77,8 \% можна прогнозувати початок наступного масового розмноження цього шкідника точно в роки-репери і з $100 \%$-ю - в роки репери і через один рік опісля. Останнє масове розмноження довгоносика в Лісостепу України спостерігали в 2009-2010 pр. із максимумом у 2009 р., коли щільність жуків в окремих осередках діходила до 48 жуків на м² (Федоренко, 2010). До 2009 р. додаємо 9 років і прогнозуємо початок наступного масового розмноження цього шкідника в 2018-2019 роках. Узагальнені дані багаторічного прогнозу масового розмноження основних шкідників буряків цукрових у Лівобережному Лісостепу України наведено в таблиці 2.

Висновки. На основі міжсистемного методу прогнозування розроблені алгоритми масового розмноження совки озимої, метелика лучного, совки капустяної, совки-гамма i довгоносика звичайного, а також прогноз початку наступних спалахів їхньої чисельності на період до 2018 року.

\section{2. Прогноз початку наступних масових розмножень основних шкідників буряків цукрових} у Лівобережному Лісостепу Украӥни

\begin{tabular}{|c|c|c|c|c|}
\hline Назва шкідника & $\begin{array}{c}\text { Роки масових } \\
\text { розмножень }\end{array}$ & $\begin{array}{c}\text { Середній період між } \\
\text { початками наступного } \\
\text { розмноження, років }\end{array}$ & $\begin{array}{c}\text { Рік максимуму } \\
\text { чисельності }\end{array}$ & $\begin{array}{c}\text { Прогноз початку } \\
\text { наступного масового } \\
\text { розмноження, рік }\end{array}$ \\
\hline Совка озима & $1813-2007$ & 9 & 2007 & 2016 \\
\hline Метелик лучний & $1854-2000$ & 10 & 2012 & 2022 \\
\hline Совка капустяна & $1871-2000$ & 7 & 2008 & 2015 \\
\hline Совка-гамма & $1826-1995$ & 9 & 2004 & 2013 \\
\hline $\begin{array}{c}\text { Довгоносик буряко- } \\
\text { вий звичайний }\end{array}$ & $1851-2009$ & 9 & 2009 & 2018 \\
\hline
\end{tabular}

\section{БІБЛІОГРАФІЯ}

1. Белецкий $\epsilon$. Н. Резкие изменения солнечной активности и массовые размножения вредных насекомых // Солнечные даные 1985 г.: Бюлл. Л. : Наука, 1985. - № 4. - С. 91-94.

2. Білецький С. М., Туренко В. П. Методологія прогнозу // Захист рослин. - 2002. - № 7. - С. 2-4.

3. Білецький $€$. М. Закономірності прогнозу масового розмноження лучного метелика // Карантин і захист рослин. - 2004. - № 9. - С. 11-13.
4. Большаков В. П. Экологическое прогнозирование. - М. : Знание, 1983. -64 с.

5. Іванов С. П. Масові розмноження шкідників і методи їх прогнозу // Вісник АН УРСР, 1936. - № 4.

6. Летопись Самовидца // Полное собрание русских летописей. -1978 . - С. 164.

7. Федоренко В. П. Академіки Національної академії аграрних наук України. - Київ, 2010. - С. 46. 